\title{
ЭФФЕКТИВНОСТЬ И ФИЗИОЛОГИЧЕСКАЯ БЕЗОПАСНОСТЬ ГОРОХА В РАЦИОНАХ КУР-НЕСУШЕК (Gallus gallus L.) РОДИТЕЛЬСКОГО СТАДА НА ПОЗДНИХ СРОКАХ СОДЕРЖАНИЯ*
}

\author{
Е.Н. АНДРИАНОВА ${ }^{\circledR}$, И.А. ЕГОРОВ 1 , В.В. ПРОНИН ${ }^{2}$
}

Известно, что применение люпина, гороха, кормовых бобов, вики удешевляет рационы птицы, однако для этих растений характерно наличие антипитательных факторов, что особенно важно учитывать в племенном птицеводстве. Ранее мы подтвердили физиологическую безопасность и производственную эффективность включения 15 \% люпина в комбикорма для кур-несушек родительского стада. Применение гороха вместо сои и люпина в качестве источника протеина позволило бы еще более удешевить финишные рационы цыплт-бройлеров и кур-несушек (особенно после пика продуктивности, когда снижается требуемое количество протеина в рационе). В настоящем работе мы впервые установили возможность непродолжительного применения 5 и $10 \%$ гороха для замены сои и продуктов переработки подсолнечника в комбикормах для племенных несушек родительского стада кросса СП 78 при удлиненных сроках содержания (53,7-71,14 нед). В наших опытах (виварий СГЦ «Загорское», ФНЦ ВНИТИП РАН, Московская обл., 2020 год) куры I (контрольной) группы потребляли рассыпные полнорационные комбикорма без гороха, комбикорма для несушек из II, III и IV групा содержали 5, 10 и 15 \% гороха, заменявшего продукты переработки сои. Содержание птицы клеточное (по $n=30$ в группе). От 65,8-недельных несушек методом искусственного осеменения получали яйцо, 100 яиц от каждой группы инкубировали (инкубатор DANKI, Бельгия) при стабильном режиме: при инкубации в течение предварительного периода (1-18 сут) около яиц поддерживалась температура $37,7^{\circ} \mathrm{C}$ (контроль с точностью до $0,1{ }^{\circ} \mathrm{C}$ с помощью датчика), в выводной период $\left(18-21\right.$ сут) $-37,2{ }^{\circ} \mathrm{C}$; относительная влажность соответственно 52-53 и 52-75 \%. Учитывали сохранность поголовья, яйценоскость; рассчитывали потребление и затраты корма на 1 гол., на 10 яиц и на 1 кг яичной массы; инкубационные показатели (оплодотворенность, выводимость); определяли содержание витаминов и каротиноидов в печени, химический состав печени, содержание кальция, фосфора в большеберцовой кости по методикам согласно действующим ГОСТ. Для оценки влияния антипитательных факторов гороха на птицу проводили гистологические исследования печени кур-несушек $(n=12)$ в возрасте 71,14 нед с целью выявления морфологических изменений. Образцы отбирали в течение 1 ч после убоя с латеральной стороны правой доли печени и фиксировали в $10 \%$ водном растворе нейтрального формалина. Установлено, что включение гороха в дозе 5 и $10 \%$ в комбикорма для кур-несушек родительского стада способствовало повышению (в сравнении с контролем) интенсивности яйценоскости на 2,38 и 4,97\% (достоверно при р $\leq 0,5$ ), выхода яичной массы в расчете на несушку на 3,78 и $12,23 \%$ при снижении числа неоплодотворенных яиц. Гистологические исследования показали, что увеличение доли гороха в рационах до $15 \%$ может приводить к цитотоксическому воздействию на гистоструктуры печени и провоцировать ее жировую дистрофию. Этот эффект следует учитывать при составлении рационов. Отметим, что горох можно использовать без предварительной термической обработки, а отрицательное воздействие пектина, таннинов, ингибиторов трипсина и протеаз уменышать за счет применения ферментных препаратов, органических кислот и гепатопротекторов.

Ключевые слова: Pisum sativum L., горох, куры-несушки, яйценоскость, вывод, выводимость, оплодотворенность, сохранность, микроморфология печени, цитотоксичность.

В себестоимости яиц и мяса птицы около 70 \% составляют затраты на корма. Для удешевления рационов используются нетрадиционные источники белка на основе подсолнечного шрота и зернобобовых культур сои, люпина, бобов, гороха (1-4). Россия - один из ведущих мировых производителей гороха (https://agrovesti.net/lib/industries/beans/rossijskij-rynokgorokha-tendentsii-i-prognozy.html), при этом основной потребитель гороха пищевая промышленность, и только малая часть используется на кормовые цели. Относительная дешевизна гороха в сравнении с соей и продуктами ее переработки служит предпосылкой для увеличения применения гороха при производстве белковых кормов в животноводстве (5). Ограничивает использование гороха в кормопроизводстве широкий спектр антипитательных

\footnotetext{
* Работа выполнена в соответствии с заданием № НИОКТР АААА-А17-117062660105-5.
} 
факторов в семенах - антигенных белков, лектинов, некрахмалистых полисахаридов, ингибиторов трипсина, 1,5-2,5 \% дубильного вещества таннина (6-8). Расширение перспектив применения гороха в кормления домашней птицы связывают с созданием сортов с низким содержанием антипитательных факторов и применением ферментных препаратов и подкислителей на основе органических кислот $(7,9)$.

В целом все бобовые культуры отличаются высокой долей протеина в зерне и обогащают рацион незаменимыми аминокислотами и минеральными веществами. Состав протеина бобовых обусловливает его высокую переваримость - 85-89 \%, что на $10 \%$ выше соответствующего показателя для белка злаковых культур (6). Горох - хороший источник незаменимой аминокислоты лизина $(10,11)$, метионин лимитирует его биологическую ценность. Современные сорта гороха российской селекции содержат 23-26 \% белка, его повышенный процент характерен для сортов, выращиваемых в Северо-Кавказском регионе (до $28 \%$ ) и в Восточной Сибири (до 25,2 \%) (5). Количество крахмала в зерне гороха в российских условиях достигает $61 \%$, особенно у гладкозерных сортов. Оболочки семян гороха составляют 8-10\% от их массы и содержат 50 \% клетчатки, 20-25 \% гемицеллюлозы, до $17 \%$ растворимых полисахаридов в виде пектина (7). Питательный состав и качество гороха зависят не только от сорта, но и от климатических условий и места выращивания (12). Из-за наличия в семенах гороха ингибиторов трипсина и высокого содержания пектина $(7,13,14)$ доступность аминокислот невысока (менее 80 \%), что снижает их фактическую переваримость.

Таннины - сложные эфиры ароматических кислот (чаще всего галловой кислоты) с углеводами. Растворы таннинов способны осаждать белки, чем обусловлено их вяжущее действие. При кислотном гидролизе или воздействии ферментом тиназой таннины распадаются с образованием более простых соединений феноловой и нефенольной природы. Как и многие фенольные соединения, таннины относятся к антипитательным веществам $(6,14,15)$, которые могут отрицательно влиять на организм животных, нарушая минеральный обмен и снижать переваримость нутриентов (6). Однако таннины в организме не накапливаются и выводятся через 3-7 ч. Кроме того, они обладают свойством осаждать ядовитые алкалоиды и соли тяжелых металлов. Снижается вредное действие таннинов добавлением в комбикорма синтетического метионина $(14,15)$.

Применение ферментных препаратов (16-18), подкислителей (9) на основе органических кислот, гепатопротекторов позволяет уменьшить отрицательное воздействие антипитательных факторов и увеличить долю гороха в комбикормах для птицы без снижения ее продуктивности $(18,19)$.

В основном эффективность применения комбикормов с включением гороха изучена на бройлерах $(9,12,15,18)$. Небольшая часть исследований посвящена применению этой культуры в кормлении несушек промышленного стада $(6,16,17,19,20)$.

В настоящее время уделяется большое внимание продлению срока содержания кур-несушек промышленного и родительского стада. С возрастом несушек энергетическую и протеиновую питательность их рационов снижают (10). Мы полагаем, что в этот период для удешевления рациона оправдано использование гороха, содержание протеина в котором ниже, чем в сое и продуктах ее переработки, принимая во внимание, что пищеварительная система взрослой птицы способна обеспечить хорошее усвоение питательных веществ из комбикормов с горохом. В известных нам публикациях по изучению влияния гороха в рационах в разные продуктивные периоды возраст несушек составлял до 50 нед $(17,19,21,22)$. Сообщения 
об эффектах комбикормов с горохом на поздних сроках содержания курнесушек родительского стада практически отсутствуют.

Ранее мы подтвердили физиологическую безопасность и производственную эффективность включения 15 \% люпина в комбикорма для курнесушек родительского стада (1). В настоящей работе мы впервые показали возможность замены горохом продуктов переработки сои и подсолнечника в комбикормах для кур-несушек родительского стада до 71,14-й нед содержания. Установлено, что непродолжительное включение гороха в комбикорма для племенной птицы в дозе 5-10\% не оказывает отрицательного воздействия на состояние печени, ее микроморфологию и позволяет обеспечить высокую сохранность, продуктивность и выход 1-суточного молодняка, не уступающие таковым у птицы, получавшей продукты переработки сои. Увеличение доли гороха до 10-15 \% в сочетании с продолжительным скармливанием снижает продуктивность несушек и повышает вероятность жировой дистрофии печени.

Цель исследования - охарактеризовать биологическое и продуктивное действие гороха при его включении в комбикорма кур-несушек родительского стада как потенциальной альтернативы продуктам переработки сои и подсолнечника.

Методика. Исследования выполняли на четырех группах (по $n=30)$ кур-несушек (Gallus gallus L.) кросса СП 789 в течение 4 мес продуктивного периода, начиная со 376- до 498-суточного возраста (виварий СГЦ «Загорское», ФНЦ ВНИТИП РАН, Московская обл., 2020 год). Использованный в качестве кормового ингредиента горох содержал 21,3\% протеина, 1,5 \% жира, 5,8 \% клетчатки, 1,53 \% лизина, 0,22 \% метионина (анализ выполнен в Испытательном центре ФНЦ ВНИТИП РАН). Питательность комбикормов, нормы посадки, световой, температурный и влажностный режим, фронт кормления и поения на протяжении всего опыта соответствовали рекомендациям Всероссийского научно-исследовательского и технологического института птицеводства (ВНИТИП, М., 2014). Несушки из I группы (контроль) получали сбалансированные рассыпные полнорационные комбикорма без включения гороха (основной рацион - OP), во II, III и IV группах продукты переработки сои в комбикормах заменяли соответственно 5, 10 и 15 \% гороха. Птицу содержали в клеточной батарее КБЛ-4 (ООО «Пятигорсксельмаш», г. Пятигорск). Корм раздавали вручную.

В возрасте 65,8 нед от несушек методом искусственного осеменения получали яйцо, которое закладывали на инкубацию (от каждой группы по 100 шт., экспериментальный инкубаторий, DANKI, Бельгия). Осеменение проводили по общепринятой методике с применением среды для разбавления спермы петухов (доза осеменения - 0,1 мл спермы, разбавленной в соотношении 1:3) (23). В течение предварительного периода инкубации (1-18-е сут около яиц) поддерживалась температура $37,7^{\circ} \mathrm{C}$ (контроль с точностью до $0,1{ }^{\circ} \mathrm{C}$ с помощью датчика), в выводной период (18-21-е сут) $37,2{ }^{\circ} \mathrm{C}$; относительная влажность - соответственно 52-53 и 52-75\%.

Учитывали основные зоотехнические показатели птицы: живую массу в начале и конце исследований (индивидуальным взвешиванием), сохранность поголовья, яйценоскость; рассчитывали потребление и затраты корма на 1 гол., на 10 яиц и на 1 кг яичной массы; упругую деформацию яиц, инкубационные показатели (оплодотворенность, выводимость), определяли содержание витаминов и каротиноидов в яйце и печени, химический состав яиц и печени, содержание кальция, фосфора в большеберцовой кости $(1,10)$.

По окончании опыта для гистологических исследований у кур-несу- 
шек $(n=12)$ в течение 1 ч после убоя однотипно брали образцы ткани с латеральной стороны правой доли печени и фиксировали их в 10 \% водном растворе нейтрального формалина. Осуществляли проводку (гистопроцесcop TLP-720, ОOО «Креоника», Россия) и заливку материала (станция ESD2800 , ООО «Креоника», Россия). Срезы толщиной 5-8 мкм готовили на ротационном полуавтоматическом микротоме RMD-3000 (OOO «Креоника», Россия) и окрашивали гематоксилином и эозином (автоматический линейном стейнер ALS-96, ООО «Креоника», Россия). Препараты исследовали с помощью микроскопа Микмед-6 («ЛОМО»,Россия), для измерения размеров гепатоцитов, трабекул, синусоидов и фотодокументирования использовали видеокамеру E31S PM («Hangzhou Touptek Photonics Co., Ltd», Китай) и программное обеспечение ToupView («Hangzhou Touptek Photonics Co., Ltd», Китай) (увеличение $\times 100$ и ×400). Измерительную шкалу видеокамеры калибровали с помощью объект-микрометра проходящего света ОМП («ЛОМО», Россия). Измеряли большой и малый диаметры гепатоцитов и их ядер, вычисляли объемы клеток, цитоплазмы и ядер, ядерно-цитоплазматическое отношение $(24,25)$. Объем гепатоцитов и ядер определяли по формуле $\mathrm{V}=\pi / 6 \times \mathrm{L} \times \mathrm{B}^{2}$, где $\mathrm{L}-$ большой диаметр клеток (ядер), мкм; B - малый диаметр клеток (ядер), мкм (25). Полученные цифровые данные подвергали биометрической обработке (26).

Для показателей учетов и измерений рассчитывали средние значения $(M)$ и ошибки средних ( $\pm \mathrm{SEM})$. Достоверность различий оценивали по $t$-критерию Стьюдента, различия считали достоверными при $\mathrm{p} \leq 0,5$.

Результаты. В зерне гороха во фракции глобулинов (простые белки, доля которых достигает 60 \%) преобладает легумин (27). Он нерастворим в воде, но хорошо растворяется в нейтральных солях. В легумине высокое содержание лизина, валина, глютаминовой кислоты, серина, треонина, но очень мало метионина и триптофана. Попадая в организм птицы, легумин может вступать в реакцию с неорганическими солями и органическими кислотами, превращаясь в вещества, недоступные для усвоения. Таннины также могут отрицательно повлиять на минеральный обмен и переваримость питательных веществ (6) (каждый процент содержания таннинов снижает переваримость протеина на $6 \%)$.

Как показали результаты (табл. 1), в нашем опыте скармливание гороха $(5,10$ и $15 \%)$ несушкам в течение 4 мес, начиная с 376-недельного возраста, не сказалось отрицательно на продуктивности и сохранности птицы. Сохранность поголовья в группах, получавших 10 и $15 \%$ гороха, составляла $100 \%$. Отход птицы во II группе, получавшей $5 \%$ гороха, составил 3,33 \% и не был связан с кормовым фактором. Птица охотно потребляла комбикорма с горохом, и по живой массе несушки II, III и IV групп в 71-недельном возрасте превосходили контроль соответственно на 3,87; 4,86 (в этой группе разница статистически значима при $\mathrm{p} \leq 0,5$ ) и $1,14 \%$. При этом в расчете на 10 яиц и на 1 кг яичной массы несушки из II, III и IV групп потребили меньше корма: соответственно на 3,12; 7,85 и 5,37 \% и на 3,$0 ; 11,16$ и 8,09\%. В группах, получавших горох, по сравнению с контролем повышалась интенсивность яйценоскости (соответственно на 2,38; 4,97 и $3,41 \%$ ) и выход яичной массы в расчете на несушку (на 3,78; 12,23 и 8,72 \%).

Несмотря на наличие в горохе ингибиторов трипсина, таннинов включение гороха в комбикорма для несушек родительского стада в изученных нами дозировках не повлияло на снижение сохранности птицы, что согласуется с результатами исследований $(19,21)$, выполненных как на цыплятах-бройлерах, так и на курах-несушках промышленного стада. 
Хорошая сохранность птицы может быть обусловлена тем, что горох способен оказывать стимулирующее влияние на синтез белков, связанных с иммунитетом. Так, сообщалось (28), что включение гороха в комбикорма для бройлеров приводило к увеличению в их крови фракции $\beta$ - и $\gamma$-глобулинов, что способствовало улучшению иммунитета птицы.

1. Продуктивность кур-несушек (Gallus gallus L.) кросса CП 789 из родительского стада в период с 376-498-суточного возраста при разном количестве гороха в рационе $(M \pm S E M$, виварий СГЦ «Загорское ЭПХ ВНИТИП», Московская обл., 2020 год)

\begin{tabular}{|c|c|c|c|c|}
\hline \multirow{2}{*}{ Показатель } & \multicolumn{4}{|c|}{ Группа (по $n=30)$} \\
\hline & I (контроль) & II $(5 \%)$ & III $(10 \%)$ & IV (15\%) \\
\hline Сохранность поголовья, \% & 100 & 96,67 & 100 & 100 \\
\hline \multicolumn{5}{|l|}{ Живая масса кур, г: } \\
\hline на начало опыта & $1669,8 \pm 23,5$ & $1733,0 \pm 24,4$ & $1698,3 \pm 18,2$ & $1674,8 \pm 18,0$ \\
\hline на конец опыта & $1720,83 \pm 30,8$ & $1787,43 \pm 41,1$ & $1804,48 \pm 50,2^{*}$ & $1740,43 \pm 32,4^{*}$ \\
\hline \multicolumn{5}{|l|}{ Потреблено корма: } \\
\hline на 1 гол/сут, г & 113,101 & 113,85 & 112,77 & 113,02 \\
\hline на 10 яиц, г & 1,861 & 1,803 & 1,715 & 1,761 \\
\hline на 1 кг яичной массы, кг & 2,866 & 2,780 & 2,546 & 2,634 \\
\hline Интенсивность яйценоскости, \% & 60,77 & 63,15 & 65,74 & 64,18 \\
\hline Средняя масса яйца, г & 64,95 & 64,85 & 67,39 & 66,86 \\
\hline Выход яичной массы на несушку, кг & 4,815 & 4,997 & 5,404 & 5,235 \\
\hline \multicolumn{5}{|l|}{ Упругая деформация, мкм: } \\
\hline в возрасте 65,8 нед & $24,60 \pm 1,71$ & $26,46 \pm 1,15$ & $23,60 \pm 1,99$ & $24,07 \pm 1,04$ \\
\hline в возрасте 71,0 нед & $27,96 \pm 1,83$ & $27,62 \pm 1,73$ & $26,76 \pm 1,30$ & $27,05 \pm 1,53$ \\
\hline \multicolumn{5}{|l|}{ Содержание в скорлупе Са, \%: } \\
\hline у кур в возрасте 53,0 нед & 36,61 & 36,61 & 36,61 & 36,61 \\
\hline у кур в возрасте 65,8 нед & 36,34 & 36,00 & 36,67 & 35,64 \\
\hline \multicolumn{5}{|l|}{$\begin{array}{l}\text { Содержание в большеберцовой кости, \% } \\
\text { (в возрасте } 71,14 \text { нед): }\end{array}$} \\
\hline зола & 60,84 & 63,75 & 59,43 & 55,86 \\
\hline $\mathrm{Ca}$ & 23,28 & 23,26 & 22,47 & 20,92 \\
\hline $\mathrm{P}$ & 9,62 & 9,59 & 9,49 & 8,85 \\
\hline
\end{tabular}

Большое значение в кормлении несушек родительского стада имеет минеральный обмен (29), обеспечивающий длительное поддержание хорошего состояния костяка кур, качества скорлупы яиц и получения кондиционного инкубационного яйца. Величина упругой деформации, характеризующая качество скорлупы яиц в 65,9-недельном возрасте в III и IV группах, получавших 10 и $15 \%$ гороха в составе комбикормов, варьировала от 23,6 до 24,07 мкм против 24,6 мкм в контроле. В возрасте 71 нед показатель упругой деформации скорлупы недостоверно снизился по сравнению с контролем (26,76-27,62 мкм против 27,96 мКм), при этом в III группе (10\% гороха в рационе) показатель был выше, чем во II и IV. Толщина скорлупы во всех группах на протяжении всего учетного периода соответствовала нормативу для кросса. К концу учетного периода депонирование кальция и фосфора в большеберцовой кости у несушек из II и III групп (5 и 10 \% гороха в составе комбикормов), сохранялось на уровне контроля, а с увеличением количества гороха до $15 \%$ - недостоверно снижалось (на 2,36 и $0,77 \%)$ (см. табл. 1).

Как известно, горох по аминокислотному составу (30) уступает сое, что может отразиться на качестве яиц и снижении их массы. В нашем опыте включение гороха в рацион не сказалось отрицательно на массе яиц: в среднем во II группе (5 \% гороха) она оставалась на уровне контроля, а в III и IV группах (10 и 15 \% гороха) - превысила контроль на 3,76 и 2,94 \%.

Анализ химического состава показал (табл. 2), что по содержанию жира инкубационные яйца от несушек II, III и IV групп превосходили контроль на 1,$41 ; 1,55$ и $1,10 \%$ (различия недостоверны), а содержание 
протеина незначительно снижалось (на 1,$30 ; 1,21$ и $0,12 \%$, различия недостоверны). По количеству золы значительных достоверных различий между группами мы также не установили.

2. Химический состав и содержание витаминов в инкубационном яйце у 65,8-недельных кур-несушек (Gallus gallus L.) кросса CП 789 из родительского стада при разном количестве гороха в рационе (в расчете на воздушно-сухое вещество, виварий СГЦ «Загорское ЭПХ ВНИТИП», Московская обл., 2020 год)

\begin{tabular}{l|c|c|c|c}
\hline \multicolumn{1}{c}{ Показатель } & \multicolumn{4}{c}{ Группа (по $n=30)$} \\
\cline { 2 - 5 } & I (контроль) & II $(5 \%)$ & III (10 \%) & IV (15 \%) \\
\hline Влага, \% & 75,34 & 74,85 & 74,89 & 73,10 \\
Протеин, \% & 50,29 & 48,99 & 49,08 & 50,17 \\
Жир, \% & 34,77 & 36,18 & 36,32 & 35,87 \\
Зола, \% & 3,28 & 3,00 & 3,18 & 3,00 \\
Витамин А, мкг/г & 9,30 & 10,73 & 7,17 & 5,45 \\
Витамин Е, мкг/г & 114,20 & 176,98 & 99,81 & 77,89 \\
Витамин В2 в желтке, мкг/г & 6,32 & 6,34 & 5,08 & 5,33 \\
Витамин В2 в белке, мкг/г & 4,22 & 4,24 & 4,02 & 4,14 \\
Каротиноиды, мкг/г & 4,22 & 5,67 & 6,24 & 7,95
\end{tabular}

П р и м е ч а и е. Анализ объединенных проб по 10 яиц каждой группы. Согласно использованной методике, различия считаются достоверными, если по содержанию протеина разница превышает $1 \%$, жира $2 \%$, жирорастворимых витаминов - $20 \%$, водорастворимых $-15 \%$.

Следует отметить, что включение гороха в комбикорма во всех группах способствовало достоверному увеличению депонирования каротиноидов в яйцах - соответственно на 1,45; 2,02 и 3,73 мкг/г. Вместе с тем при 10$15 \%$ гороха в рационах содержание витамина А снизилось на 2,13-3,85 мкг/г, витамина Е - на 14,39-36,31 мкг/г, витамина В2 - на 1,24-0,99 в желтке и на 0,20-0,08 мкг/г в белке. Достоверное снижение содержание витамина Е в яйцах отмечали у несушек, получавших 15 люпина в составе комбикорма (1).

3. Биоконтроль инкубации яиц от 65,8-недельных кур-несушек (Gallus gallus L.) кросса СП 789 из родительского стада при разном количестве гороха в рационе (виварий СГЦ «Загорское ЭПХ ВНИТИП», Московская обл., 2020 год)

\begin{tabular}{|c|c|c|c|c|}
\hline \multirow{2}{*}{ Показатель } & \multicolumn{4}{|c|}{ Группа (по 100 яиц) } \\
\hline & I (контроль) & II $(5 \%)$ & III $(10 \%)$ & IV $(15 \%)$ \\
\hline Оплодотворенность, \% & 83 & 88 & 91 & 86 \\
\hline Неоплод, \% & 17 & 12 & 9 & 14 \\
\hline Кровяные кольца & 3 & 4 & 4 & 2 \\
\hline Замершие, \% & 0 & 0 & 2 & 0 \\
\hline Тумак, \% & 1 & 0 & 0 & 0 \\
\hline Задохлики, \% & 5 & 4 & 0 & 10 \\
\hline Слабые, гол. & 1 & 3 & 2 & 3 \\
\hline Выводимость, \% & 89,16 & 90,91 & 93,41 & 86,05 \\
\hline Вывод, \% & 74 & 89 & 85 & 74 \\
\hline \multicolumn{5}{|l|}{ Получено, гол: } \\
\hline кондиционных цыплят & 73 & 77 & 83 & 71 \\
\hline всего цыплят & 74 & 80 & 85 & 74 \\
\hline
\end{tabular}

Полноценное развитие эмбриона в начале инкубационного периода влияет на количественные и качественные результаты инкубации $(19,23)$. Оплодотворенность яиц у несушек 65,8-недельного возраста составляла 83$91 \%$ и была выше в сравнении с контролем у всех кур, получавших горох (соответственно на 5; 8 и 3 \%) (табл. 3). У несушек, получавших 5 и $10 \%$ гороха в составе комбикормов, отход при инкубации был ниже контроля на 1 и $3 \%$. Однако в поздний период инкубации отмечалось значительное увеличение числа задохликов в IV группе (15\% гороха), что затем проявилось в ухудшении инкубационных показателей - снижении выводимости цыплят (86,05 \% против 89,16\% в контроле) и уменьшении числа кондиционных цыплят на 2,74 \%. Таким образом, использование 5-10 \% гороха в рационах 
кур-несушек эффективнее, повышает вывод цыплят в сравнении с контролем на 5 и $11 \%$ и позволяет получить больше (на 5,48 и 13,7 \%) кондиционных цыплят.

Ранее отмечали сходные результаты по сохранению качества инкубационных яиц и выводу цыплят (19), а также при включении 20 \% гороха в сочетании с препаратом CELLOVIRIDIN G20X (Россия) (60-70 г/т корма) в комбикорма для мясных кур $(17,19)$. Необходимо отметить, что применение ферментных препаратов позволяет эффективно заменять соевый шрот горохом в рационах кур-несушек, и при этом интенсивность яйцекладки и качество яиц остаются высокими $(21,22,31)$.

При длительных сроках содержания птицы снижение яйценоскости и сохранности несушек, ухудшение качества инкубационного яйца часто обусловлено жировой дистрофией печени у несушек, которую могут провоцировать антипитательные факторы кормов $(6,10)$. Выявленное повышение накопления жира в печени несушек из групп, потреблявших комбикорма с разным количеством гороха в рационе (табл. 4), послужило основанием для гистологического исследования этого органа, чтобы установить оптимальную дозировку гороха в рационе.

4. Химический состав (\%) печени у 65,8-недельных кур-несушек (Gallus gallus $\mathbf{L}$.) кросса СП 789 из родительского стада при разном количестве гороха в рационе $(n=12$, виварий СГЦ «Загорское ЭПХ ВНИТИП», Московская обл., 2020 год)

\begin{tabular}{l|c|c|c|c}
\hline \multirow{2}{*}{ Показатель } & \multicolumn{4}{c}{ Группа } \\
\cline { 2 - 5 } & I (контроль) & II (5\%) & III (10 \%) & IV (15\%) \\
\hline Влага & 69,40 & 64,04 & 65,92 & 69,98 \\
Протеин & 52,34 & 49,66 & 46,20 & 46,93 \\
Жир & 25,49 & 40,71 & 33,08 & 25,53 \\
Зола & 3,88 & 3,68 & 3,90 & 3,88 \\
П р и м е ч а н и е. Анализ объединенных проб печени от трех несушек. Согласно использованной мето- \\
дике, различия считаются достоверными, если по содержанию протеина разница превышает $1 \%$, жира - \\
$2 \%$.
\end{tabular}

5. Морфометрические показатели печени у 65,8-недельных кур-несушек (Gallus gallus L.) кросса CП 789 из родительского стада при разном количестве гороха в рационе $(n=12, M \pm \mathrm{SEM}$, виварий СГЦ «Загорское ЭПХ ВНИТИП», Московская обл., 2020 год)

\begin{tabular}{|c|c|c|c|c|}
\hline \multirow{2}{*}{ Показатель } & \multicolumn{4}{|c|}{ Группа } \\
\hline & I (контроль) & II $(5 \%)$ & III $(10 \%)$ & IV (15\%) \\
\hline Объем гепатоцита, мкм³ & $471,50 \pm 18,21$ & $465,13 \pm 14,48$ & $496,12 \pm 16,88$ & $468,24 \pm 12,51$ \\
\hline Объем ядра, мкм ${ }^{3}$ & $41,44 \pm 3,11$ & $39,18 \pm 3,42$ & $39,47 \pm 3,18$ & $41,66 \pm 4,56$ \\
\hline Объем цитоплазмы, мкм³ & $430,99 \pm 23,40$ & $426,71 \pm 22,75$ & $457,63 \pm 29,87$ & $427,87 \pm 31,14$ \\
\hline Ядерно-цитоплазматическое отношение & $0,09 \pm 0,01$ & $0,09 \pm 0,01$ & $0,09 \pm 0,01$ & $0,10 \pm 0,01$ \\
\hline Трабекулы, мкм & $11,27 \pm 1,43$ & $14,33 \pm 1,56$ & $13,48 \pm 1,71$ & $17,92 \pm 1,98$ \\
\hline Синусоиды, мкм & $8,42 \pm 1,07$ & $10,57 \pm 1,11$ & $9,88 \pm 1,17$ & $8,84 \pm 1,19$ \\
\hline
\end{tabular}

Несмотря на то, что при морфометрическом исследовании мы не обнаружили достоверно значимых различий между контрольной и опытными группами (табл. 5), количество гороха в рационе повлияло на степень наблюдаемых деструктивных изменений к 71,14-недельному возрасту. Гистологические исследования печени кур-несушек показали наименьшие поражения печени у птицы из контрольной группы. Установлено, что гистоструктуры печени имели характерное строение, состояли из стромы и паренхимы. Строма представлена соединительнотканной капсулой и междольковыми перегородками. От капсулы местами вглубь органа отходят слабо выраженные соединительнотканные перегородки, дольчатое строение не выражено. Гепатоциты формируют печеночные балки, которые имеют 
ветвистый, извилистый вид. В просвете центральных вен и ветвей воротной вены встречаются форменные элементы крови. Границы гепатоцитов не выражены, клетки полигональной формы, цитоплазма окрашена неравномерно, ядра расположены, как правило, в центре, местами эксцентрично, округлой формы, содержат 1-2 ядрышка (рис., А).

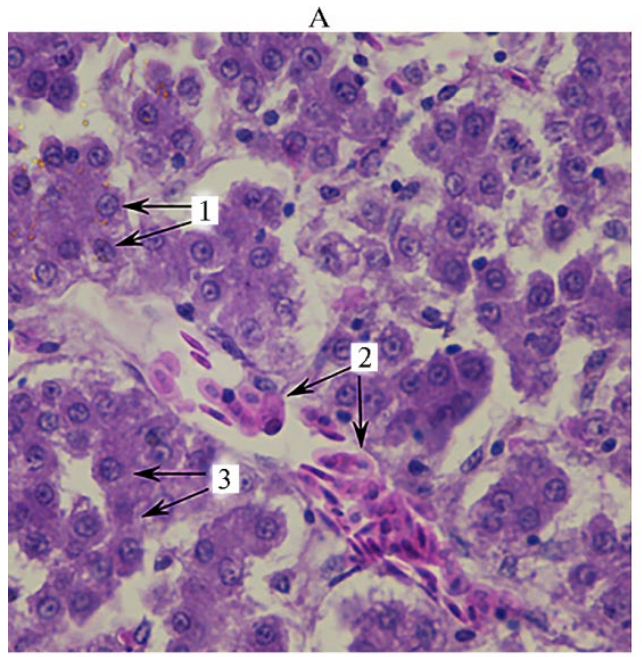

B

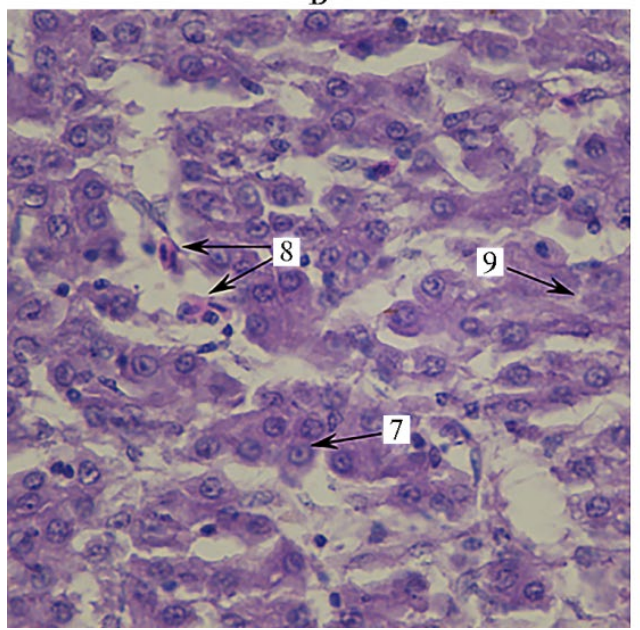

Б

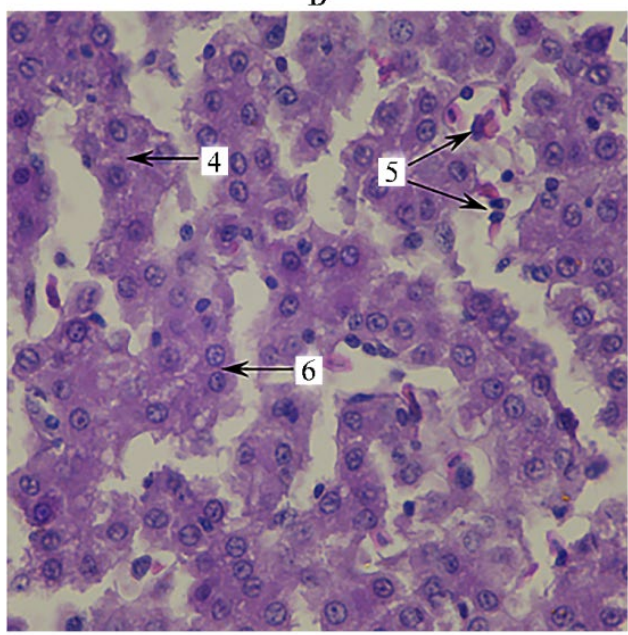

$\Gamma$

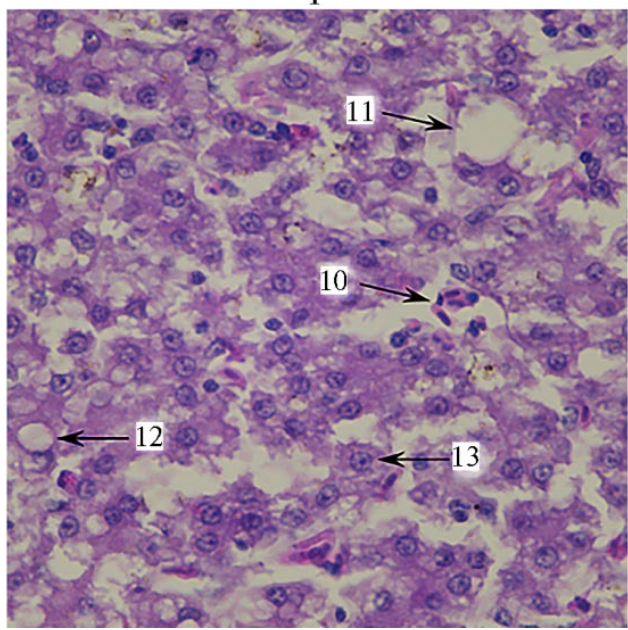

Микроморфология печени у 71,14-недельных кур-несушек (Gallus gallus L.) кросса CП 789 из родительского стада при разном количестве гороха в рационе: A - I группа (контроль, без гороха, 1 - гепатоциты, 2 - центральная вена с эритроцитами, 3 - печеночные балки); Б - II группа (5 \% гороха, 4 - гепатоциты с пенистой цитоплазмой, 5 - синусоидные капилляры, 6 - печеночные балки); В - III группа (10 \% гороха, 7 - гепатоциты, 8 - синусоидные капилляры с эритроцтиами, 9 - печеночные балки); Г - IV группа (15\%,10 - синусоидные капилляры с эритроцитами, 11 - крупные жировые включения в цитоплазме гепатоцита, 12 - мелкие жировые включения в цитоплазме гепатоцита, 13 - гепатоциты, 14 - печеночные балки). Окрашивание гематоксилином и эозином; световая микроскопия (Микмед-6, «ЛОМО», Россия), увеличение ×400. Виварий СГЦ «Загорское ЭПХ ВНИТИП» (Московская обл., 2020 год).

Структура печени кур из II группы характеризовалась незначительными признаками жировой дистрофии - цитоплазма некоторых клеток пенистая, границы между клетками не определяются, границы ядер четко очерчены, в них хорошо различимы ядрышки, незначительно расширены синусоидные капилляры, балочное строение сохранено (см. рис., Б).

Гистоструктура печени кур из III группы свидетельствует о нарушении балочного строения, гепатоциты различной формы (от овальной до 
неправильно многоугольной), границы между ними не определяются, цитоплазма клеток мутная, зернистая, выражены признаки зернисто-белкой дистрофии, ядра расположены, как правило, в центре клетки, у части гепатоцитов ядра не выявляются, в синусоидных капиллярах встречаются единичные эритроциты (см. рис., В).

Гистологическая картина печени кур IV группы свидетельствует о выраженной жировой дистрофии печени. В строме и паренхиме встречаются единичные клетки лимфоидного ряда, в синусоидных капиллярах единичные эритроциты. Балочное строение не сохранено, в цитоплазме большинства клеток отмечено значительное число крупных и мелких жировых включений, которые смещают ядра на периферию, и такие клетки имеют перстневидную форму. В части клеток граница ядер не определяется или они отсутствуют (см. рис., Г).

Сообщалось об изменении морфологии кишечника (укорочение ворсинок, уменьшение площади их поверхности и глубины крипт) у бройлеров, в рацион которых входил горох, по сравнению с птицей, получавшей сою (32). При добавлении к рациону 20 \% сырых или термически обработанных семян чины посевной (Lathyrus sativus) отмечали изменения размера поджелудочной железы и глубины крипт кишечника (33). Данных о влиянии гороха в рационе на гистоструктуру печени птицы в доступной литературе мы не обнаружили. По-видимому, избыточное содержание растительного белка в III и IV группах приводит к ухудшению метаболической функции печени, что отражается на содержании в ней липидов.

Безусловно, разработка новых сортов гороха $(34,35)$, усовершенствование способов его обработки (36), использование ферментных препаратов $(9,21)$ позволят полнее использовать эту бобовую культуру в птицеводстве не только в кормлении кур-несушек до 50-недельного возраста, но и включать его в комбикорма промышленной и племенной птицы и в поздние возрастные периоды.

Итак, нами установлена возможность непродолжительного включения в комбикорма для племенных несушек 5-10\% гороха, содержащего 21,30 \% протеина, 1,50 \% жира, 5,80 \% клетчатки, 1,53\% лизина, 0,22 \% метионина, для замены сои и продуктов переработки подсолнечника. Включение гороха в количестве 5 и 10 \% в комбикорма для кур-несушек родительского стада в позднепродуктивный период (53,7-71,14 нед) повышает интенсивность яйценоскости на 2,38 и 4,97 \% в сравнении с контролем и увеличивает выход яичной массы в расчете на несушку на 3,78 и 12,23 \% при снижении числа неоплодотворенных яиц. Результаты гистологических исследований свидетельствуют, что увеличение количества гороха в рационах до 10-15\% может приводить к цитотоксическим эффектам, изменению гистоструктуры и жировой дистрофии печени. Тем не менее зоотехнические и инкубационные показателей позволяют утверждать, что с целью удешевления комбикормов для кур-несушек родительского стада вместо продуктов переработки сои и подсолнечника в течение непродолжительного времени в рационы можно включать 5-10 \% семян гороха.

\section{ЛИТЕРАТ УРА}

1. Андрианова Е.Н., Егоров И.А., Григорьева Е.Н., Шевяков А.Н., Пронин В.В. Люпин в кормлении кур-несушек родительского стада. Сельскохозяйственная биология, 2019, 54(2): 326-336 (doi: 10.15389/agrobiology.2019.2.326rus).

2. Difo V.H, Patiene C.K, Elmugheira M.I.M. Under-utilized legumes as potential poultry feed ingredients: a mini- review. Archives of Animal \& Poultry Sciences, 2018, 1(1): 555551. 
3. Kowalska E., Kucharska-Gaca J., Kuźniacka J., Lewko L., Gornowicz E., Biesek J., Adamski M. Quality of eggs, concentration of lysozyme in albumen, and fatty acids in yolk in relation to blue lupin-rich diet and production cycle. Animals (Basel), 2020, 10(4): 735 (doi: 10.3390/ani10040735).

4. Gueguen J., Cerletti P. Proteins of some legume seeds: soybean, pea, faba bean and lupin. In: New and developing sources of food proteins /B.J.F. Hudson (ed.). Springer, Boston, MA, 1994: 145-193 (doi: 10.1007/978-1-4615-2652-0_6).

5. Околелова Т., Савченко В, Просвирякова О. Если удешевлять комбикорм горохом. Животноводство России, 2009, 4: 51.

6. Zuber T., Siegert W., Salehi H., Hummel F., Rodehutscord M. Variability of amino acid digestibility of lupin and pea grains in caecectomised laying hens. Br. Poult. Sci., 2019, 60(3): 229-240 (doi: 10.1080/00071668.2018.1556389).

7. Борисенко К.В., Вертипрахов В.Г. Влияние ввода кормовой протеазы на продуктивность, переваримость питательных веществ, биохимические показатели крови цыплят-бройлеров. Зоотехния, 2019, 2: 20-26 (doi: 10.25708/ZT.2019.25.87.005).

8. Castell A.G., Guenter W., Igbasan F.A. Nutritive value of peas for nonruminant diets. Animal Feed Science and Technology, 1996, 60: 209-227 (doi: 10.1016/0377-8401(96)00979-0).

9. Okolelova T., Shchukina S. Using efficiency of acidifying agent Biotronic and enzymes in mixed feed with high pea content for broilers. World's Poultry Science Journal, 2006, 62: 395.

10. Егоров И.А., Манукян В.А., Околелова Т.М., Ленкова Т.Н., Андрианова Е.Н., Шевяков А.Н., Егорова Т.В., Егорова Т.А., Байковская Е.Ю., Гогина Н.Н., Криворучко Л.И., Сысоева И.Г., Меньшенин И.А., Григорьева Е.Н., Панин И.Г., Гречишников В.В., Панин А.И., Кустова С.В., Афанасьев В.А., Пономаренко Ю.А. Руководство по кормлению сельскохозяйственной птицы /Под ред. В.И. Фисинина, И.А. Егорова. Сергиев Посад, 2018.

11. Rubio L.A., Pérez A., Ruiz R., Guzmán M.Á., Aranda-Olmedo I., Clemente A. Characterization of pea (Pisum sativum) seed protein fractions. J. Sci. Food Agric., 2014, 94(2): 280-287 (doi: 10.1002/jsfa.6250).

12. Witten S., Grashorn M.A., Aulrich K. Precaecal digestibility of crude protein and amino acid of field bean (Vicia faba L.) and field pea (Pisum sativum L.) variety for broilers. Animal Feed Science and Technology, 2018, 243: 35-40 (doi: 10.1016/j.anifeedsci.2018.07.001).

13. Grosjean F., Barrier-Guillot B., Bastianelli D., Rudeaux F., Bourdillon A., Pegronnet C. Feeding value of three categories of pea (Pisum sativum L.) for poultry. Animal Science, 1999, 69: 591-599 (doi: 10.1017/S1357729800051444).

14. Lemme A., Ravindran V., Bryden W.L. Ileal digestibility of amino acids in feed ingredients for broilers. World's Poultry Science Journal, 2004, 60: 423-437 (doi: 10.1079/WPS200426).

15. Longstaff M., Mcnab J.M. The inhibitory effects of hull polysaccharides and tannins of field beans (Vicia faba L.) on the digestion of amino acids, starch and lipid and digestive enzyme activities in young chicks. British Journal of Nutrition, 1991, 65: 199-216 (doi: 10.1079/bjn19910081).

16. Igbasan F.A., Guenter W. The influence of micronization, dehulling and enzyme supplementation on the nutritional value of peas for laying hens. Poultry Science, 1997, 76: 331-337 (doi: $10.1093 / \mathrm{ps} / 76.2 .331)$.

17. Околелова Т. Целловиридин в комбикормах нестандартной рецептуры. Комбикорма, 2003, 5: 46-47.

18. Koivunen E., Talvio E., Valkonen E., Tupasela T., Tuunainen P., Valaja J. Use semi-leafless peas (Pisum sativum L.) with enzyme addition in diets for broilers. Agricultural and Food Science, 2016, 25: 90-98 (doi: 10.23986/afsci.56122).

19. Бевзюк В. Горох в рационе мясных кур. Птицеводство, 2004, 1: 18-19.

20. Мустафин А., Имангулов Ш. Горох в комбикормах для яичных кур-несушек. Птицеводство, 2005, 5: 26.

21. Ciurescu G., Pan C.O. Effect of dietary untreated field pea (Pisum sativum L.) as substitute for soybean meal and enzymes supplementation on egg production and quality of laying hens. $R o-$ manian Biotechnological Letters, 2017, 22(1): 12204-12213.

22. Kuźniacka J., Biesek J., Banaszak M., Grabowicz M., Adamski M. The quality of eggs from Rosa 1 hens fed diets containing seeds of legume plants (Lupinus luteus L., Lupinus angustifolius, and Pisum sativum) in two laying phases. Animals (Basel), 2020, 10(11): 1942 (doi: 10.3390/ani10111942).

23. Коноплева А.П., Трохолис Т. Совершенствование технологии искусственного осеменения кур яичных кроссов. В сб.: Труды ВНИТИП. Сергиев Посад, 2012, вып. 86: 24-35.

24. Автандилов Г.Г., Яблучанский Н.И., Губенко В.Г. Системная стереометрия в изучении патологического процесса. М., 1981.

25. Ташкэ К. Введение в количественную цито-гистологическую морфологию. Будапешт, 1980.

26. Лакин Г.Ф. Биометрия. М., 1990.

27. Chmielnicka A., Żabka A., Winnicki K., Polit J.T. Plant storage proteins - the main nourishing products - from biosynthesis to cellular storage depots. Postepy Hig. Med. Dosw. [Advances in Hygiene and Experimental Medicine], 2017, 71(0): 530-540 (doi: 10.5604/01.3001.0010.3834).

28. Bingol N.T., Dede S.I., Karsli M.A., Değer Y., Kiliçalp Kılınç D., Çetin S. Effects of the replacement of soybean meal with pea as dietary protein source on the serum protein fractions of 
broilers. Brazilian Journal of Poultry Science, 2016, 18(4): 639-644 (doi: 10.1590/1806-9061-20160270).

29. Zafar M.H., Fatima M. Efficiency comparison of organic and inorganic minerals in poultry nutrition: a review. PSM Vet. Res., 2018, 3(2): 53-59.

30. Leterme P., Monmart T., Baudart, E. Amino acid composition of pea (Pisum sativum) proteins and protein profile of pea flour. J. Sci. Food Agric., 1990, 53: 107-110 (doi: 10.1002/jsfa.2740530112).

31. Fru-Nji F., Niess E., Pfeffer E. Effect of graded replacement of soybean meal by faba beans (Vicia faba L.) or field peas (Pisum sativum L.) in rations for laying hens on egg production and quality. The Journal of Poultry Science, 2007, 44: 34-41 (doi: 10.2141/jpsa.44.34).

32. Röhe I., Goodarzi Boroojeni F., Zentek J. Effect of feeding soybean meal and differently processed peas on intestinal morphology and functional glucose transport in the small intestine of broilers. Poultry Science, 2017, 96(11): 4075-4084 (doi: 10.3382/ps/pex19).

33. Riasi A., Mahdavi A.H., Bayat E. Effect of different levels of raw and heated grass pea seed (Lathyrus sativus) on nutrient digestibility, intestinal villus morphology and growth performance of broiler chicks. J. Anim. Physiol. Anim. Nutr. (Berl.), 2015, 99(5): 924-931 (doi: 10.1111/jpn.12319).

34. Rao G., Shrivastava S. Toxic and antinutritional factors of new varieties of pea seeds. Research Journal of Pharmaceutical, Biological and Chemical Sciences, 2011, 2: 512-523.

35. Witten S., Böhm H., Aulrich K. Effect of variety and environment on the contents of crude nutrients, lysine, methionine and cysteine in organically produced field peas (Pisum sativum L.) and field beans (Vicia faba L.). Landbauforschung - Appl. Agric. Forestry Res., 2015, 65(3/4): 205216 (doi: 10.3220/LBF1447765843000).

36. Hejdysz M., Kaczmarek S.A., Rutkowski A. Effect of extrusion on the nutritional value of peas for broiler chickens. Arch. Anim. Nutr., 2016, 70(5): 364-377 (doi: 10.1080/1745039X.2016.1206736).

\author{
1 ФГБУ ФНЦ Всероссийский научно-исследовательский \\ и технологический институт птицеводства, \\ 141311 Россия, г. Сергиев-Посад, Московская обл., ул. Птицеградская, 10, \\ e-mail: andrianova@vnitip.ru $\bowtie$, olga@vnitip.ru,vnitip@vnitip.ru, \\ alex.shevy@mail.ru; \\ 2ФГБУ Федеральный иентр охраны здоровья животных, \\ 600901 Россия, г. Владимир, мкр. Юрьевец, ФГБУ ВНИИЗЖ, \\ e-mail: proninvv63@mail.ru
}

Поступила в редакцию

\title{
EFFICIENCY AND PHYSIOLOGICAL SAFETY OF PEAS IN THE DIETS FOR HENS (Gallus gallus L.) OF THE PARENT FLOCK DURING THE LATE LAYING PERIOD
}

\author{
E.N. Andrianova ${ }^{1}$, I.A. Egorov ${ }^{1}$, V.V. Pronin ${ }^{2}$
}

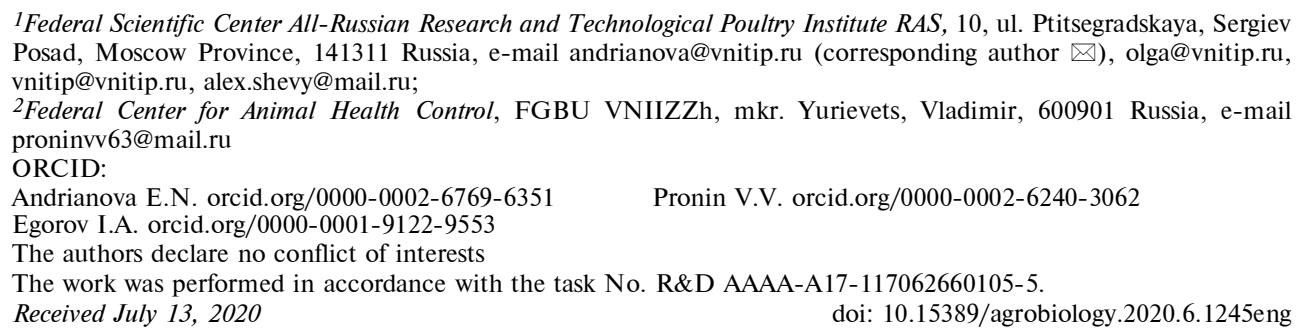

\section{Abstract}

Feeds are accounted for ca. $70 \%$ of the commercial production costs of eggs and poultry meat. The use of other legumes (lupine, peas, horse beans, vetch) can lower the feed costs. However, the antinutritive factors of the legumes should be taken into account in the receipt formulation, especially in diets for pedigree flocks. Earlier we have proven physiological safety and effectiveness of the inclusion of $15 \%$ of lupine in diets for layer parental flock. The substitution of peas for soybeans and lupine as the dietary protein source can further lower the costs of finisher diets for broilers and postpeak diets for layers where reduced protein levels are required. In the study presented we found efficient the substitution of peas (5 and $10 \%$ ) for soybean meal and sunflower cake in diets for parental flock of cage-housed layer chicken (cross SP 78, 30 birds per treatment) at the end of prolonged productive period (54-71 weeks of age). Control treatment 1 was fed the complete mash compound feed with soybeans as protein source; in diets for treatments 2,3 , and 4 the soybeans were increasingly substituted by peas $(5,10$, and $15 \%$ of total diet, respectively). After the artificial insemination 100 eggs from 
each treatment was taken since 70 weeks of age and incubated in DANKI incubator (Belgium) in constant regime. The temperature was set at $37.7^{\circ} \mathrm{C}$ during $1-18$ days of incubation and $37.2^{\circ} \mathrm{C}$ during 18-21 days and controlled with the accuracy $0.1{ }^{\circ} \mathrm{C}$; the relative humidity during these periods was 5253 and 52-75 \%, respectively. Mortality level, egg production, feed conversion ratios (per 10 eggs and per $1 \mathrm{~kg}$ of eggs laid), egg fertility and hatchability were recorded. The concentrations of vitamins and caroteniods in liver, chemical composition of liver, tibial concentrations of calcium and phosphorus were determined according to standard methods. The effects of the antinutritive factors were assessed via the histological study of the liver (at 71 weeks of age, $n=12$ ); the samples were taken in 1 hour after the euthanasia from the similar liver part (lateral side of the right lobe) and fixed in $10 \%$ neutral aqueous formalin. It was found that the inclusion of 5 and $10 \%$ of peas into the diets of parental layer flock increased the intensity of lay by 2.38 and $4.97 \%$ in compare to control, respectively, output of egg mass per hen housed by 3.78 and $12.23 \%$; the percentage of infertile eggs in these treatments was lower in compare to control. The histological study of liver revealed that $15 \%$ of peas can launch the cytotoxic effect on the hepatic structures and induce the hepatic steatosis. This effect should be taken into account in the receipt formulations. It could be also concluded that peas can be included into the diets without preliminary thermal treatment; the antinutritive effects of pectin, trypsin inhibitors and proteases, tannins could be alleviated via the additional supplementation of the diets with exogenous enzymes, organic acids, and hepatoprotective agents.

Keywords: Pisum sativum L., peas, laying hens, egg production, hatch of chicks, hatchability of eggs, fertility of eggs, mortality, hepatic histology. 